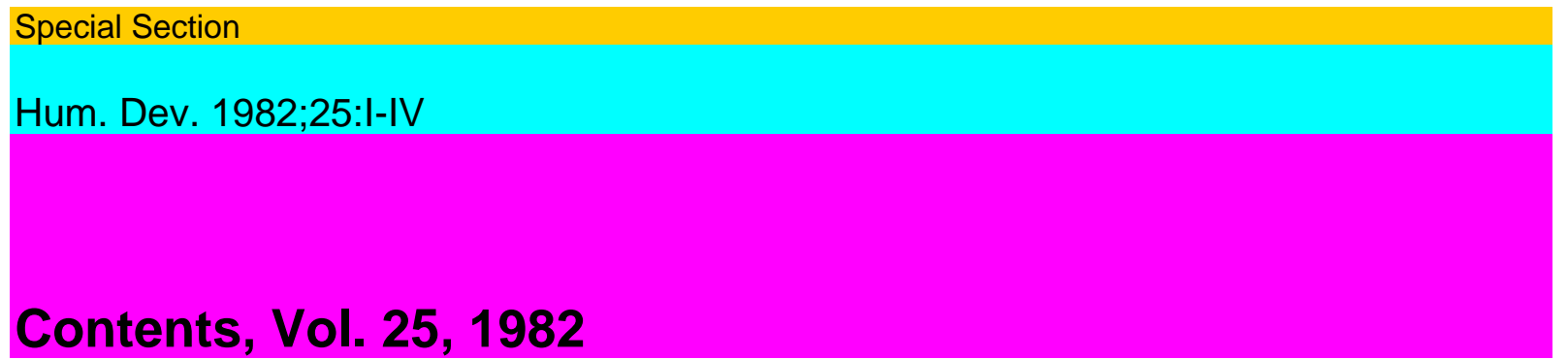

\title{
Contents Vol. 25,1982
}

No. 1 Original Paper

On Negativism

Wenar, C 1

Sex Differences in Intellectual Performance during Middle Age

Shanan, J.; Sagiv, R 24

Developmental Issue

Structuralist Perspectives on Social Development in Youth

Santilli, N.R.; Meacham, J.A 34

Proceedings

Child Development: Life-Span Perspectives (Introduction)

Lerner, R.M 38

Infancy and Life-Span Development

Lipsitt, L.P 41

The Early Training Project: A Life-Span View

Gray, S.W.; Ramsey, B.K 48

Economic Deprivation and Problem Behavior: Childhood and Adolescence in the Great

Depression

Rockwell, R.C.; Elder, G.H., Jr

Growth and Aging in Life Span Perspective

Labouvie-Vief, G 65

Commentary

Kuhn, D 79

No. 2 Original Paper

Learning and Development: the Problems of Compatibility, Access and Induction

Brown, A.L 89

Gender Typing and Androgyny in Later Life. New Directions for Theory and Research

McGee, J.; Wells, K 116

Developmental Issues

Development of the Intention to Communicate

Harding, C.G 140

On the Concepts of Period, Phase, Stage, and Level

Glasersfeld, E. von; Kelley, M.F 152

111

3 Original Paper

Dynamic Development and Mature Autonomy. A Theoretical Prologue

Labouvie-Vief, G 161

Parental Beliefs about Developmental Processes

McGillicuddy-DeLisi, A.V 192 
Conservations and Décaíage

Bovet, M.C.; Domahidy-Dami, C; Sinclair, H

201

Developmental Issues

Current Status of Research on Second-Language Learning in Children

McLaughlin, B 215

Isolationism in Adolescent Research

Grinder, R.E 223

$4 \quad$ Original Paper

Holism and the Organismic Model in Developmental Psychology

Kitchener, R.F233

Competence, Contingency, and the Development of Perceived Control

Weisz, J.R.; Stipek, D.J 250

Rethinking Piaget's Theory of Infancy

Smillie, D 282

Action and Interaction: the Study of Social Cognition in Germany and the United States

Chapman, M 295

Developmental Issue

Werner's Influences on Contemporary Psychology

Pea, R.D 303

$5 \quad$ Original Paper

The Construction of Logical Necessity

Moshman, D.; Timmons, M 309

The External Validity of Research Involving American Minorities

Washington, E.D.; McLoyd, V.C 324

Behavior Analysis and Developmental Psychology

Morris, E.K.; Hursh, D.E.; Winston, A.S.; Gelfand, D.M.; Hartmann, D.P.; Reese, H.W.;

Baer, D.M 340

Developmental Issue

John Macmurray's Philosophy of the Form of the Personal. An Overview

Furth, $\mathrm{H} \quad 365$

6 Original Paper

Infant and Family Development: From Triads to Tetrads

Kreppner, K.; Paulsen, S.; Schuetze; Y 373

Pretense and Peer Behavior: an Intersectoral Analysis

Fein, G.G.; Moorin, E.R.; Enslein, J 392

Regulatory Structures of the Self and 'Postforma $\mathrm{\Gamma}$ Stages in Adulthood

Edelstein, W.; Noam, G 407

IV

Conten

A Comment on the Meanings of 'Dialectics'

Reese, H.W 42

Social Interaction and Social Cognition in Aging. A Contextual Analysis

Dolen, L.S.; Bearison, D.J 431

Developmental Issue

Current Issues in the Study of Children's Play

Pepler, D.J.; Rubin, K.H 
Editorial Policy

Announcement

Author Index

Subject Index

Contents Vol. 25
448

450

451

452

after 452

S. Karger · Medical and Scientific Publishers · Basel · München $\square$ Paris $\square$ London · New York · Tokyo - Sydney

Drug Dosage

The authors and the publisher have exerted every effort to ensure that drug selection and dosage set forth in this text are in accord with current recommendations and practice at the time of publication. However, in view of ongoing research, changes in government regulations, and the constant flow of information relating to drug therapy and drug reactions, the reader is urged to check the package insert for each drug for any change in indications and dosage and for added warnings and precautions. This is particularly important when the recommended agent is a new and/or infrequently employed drug.

All rights reserved.

No part of this publication may be translated into other languages, reproduced or utilized in any form or by any means, electronic or mechanical, including photocopying, recording, microcopying, or by any information storage and retrieval system, without permission in writing from the publisher.

S. Karger AG, P.O. Box, CH-4009 Basel (Switzerland) Printed in Switzerland by Thür AG Offsetdruck, Pratteln 